\title{
The Use of Social Digital Networks by NGDO from a Social Marketing Perspective
}

\author{
Araceli Galiano-Coronil *(D) and Juan José MierTerán-Franco \\ Marketing and Communication Department, Faculty of Social Sciences and Communication, \\ University of Cadiz, Avenida de la Universidad s/n, 4, 11406 Jerez de la Frontera, Spain; \\ juanjose.mier-teran@uca.es \\ * Correspondence: araceli.galiano@uca.es
}

Received: 12 May 2019; Accepted: 12 June 2019; Published: 18 June 2019

check for updates

\begin{abstract}
The social marketing paradigm has been changing due to the use of digital social networks. This causes Non-Governmental Development Organizations' efforts to focus on achieving a greater reaction from the public in these communication channels. We propose that the way forward is to analyze aspects of messages that give rise to a greater response from the audience. In this regard, we have analyzed 3608 Facebook and Twitter publications with the combination of content analysis and correlation analysis. We have considered three aspects: purpose, theme, and quality of the message. We have also listed a breakdown of quality and purpose parameters in order to become more fully acquainted with these aspects. The objectives of this research are firstly to carry out the communication profiles of the NGDOs studied from the points of view of the organizations and the public. Secondly, to analyze the reaction from the public (interactions) measured by the sum of likes plus the number of shares for each post, on Facebook and Twitter, according the parameters considered. The results showed that the most published messages from the organizations do not usually coincide with those that have the most impact on the public. Another proven aspect is that Twitter posts about behavior have more effectiveness than informative messages. Likewise, quality aspects, such as hashtags, mentions, or links, are not succeeding in generating public reaction.
\end{abstract}

Keywords: Facebook; Twitter; marketing in NPO; social marketing; content marketing

\section{Introduction}

In the 1990s, several changes emerged in advanced economies, fostered by new advances in information and communication technology. Currently, more than 3 billion people around the world use social media each month (Hootsuite 2018). In Spain, 85\% of Internet users aged 16-65 use social networks, which represents more than 25.5 million users, and the most known social networks are Facebook (96\%) and Twitter (89\%) (IAB Spain, and Elogia 2018).

In this context, digital social networks have become virtual instruments to facilitate co-creation, collective knowledge, and generalized trust, with content that can be enriched with multimedia elements (Fonseca 2014; Kannan and Alice 2017; Shawky et al. 2019). These characteristics, together with the interaction, immediacy, and public character of the conversations, have made social digital networks (SDN) an indispensable component of development marketing strategies. This is also an extended phenomenon that has not gone unnoticed by development NGOs (NGDOs). For these organizations, social networks offer two types of advantages. On the one hand, they are low cost resources and do not require extensive knowledge. On the other hand, they are an excellent way to network with other people and similar organizations to know what is said about them on the Internet and to communicate content to donors, volunteers, and partners (Arroyo et al. 2012; Fonseca 2014). 
Despite the multiple advantages derived from the use of SDN, there is evidence that NGDOs do not take advantage of their full potential. This could be because they may not feel the need to establish goals or achievements in their digital activities, or they have unrealistic expectations about audience participation, do not properly manage these activities, and do not have appropriate online marketing strategies. This situation is marked by an accelerated and inadequate incorporation of social networks (Aldás and Santolino 2015; Henley and Guidry 2004) without taking into consideration other weaknesses, such as the lack of computer resources and the digital divide (Silva et al. 2018). In this sense, organizations should focus their efforts on understanding the use of SDN instead of using most of their resources to achieve a change in behavior, which is the main goal of social marketing (Hestres 2014). It is difficult to measure results related to this aim, and as a consequence it is also difficult to estimate the effectiveness (to the extent that the requirements of a given customer are met). The behavioral factors, improved attitudes, knowledge, or perceived self-efficacy may facilitate the end goal of social marketing, but do not provide sufficient evidence that social marketing interventions have achieved their stated purpose (Firestone et al. 2017). In a digital environment, social marketing can go beyond creating awareness and changing behaviors (Kotler 2011). This means that NGDOs must get users to talk about social causes through their social networks, and thus get the information they disseminate to become viral. In this sense we focus this study on social marketing communication posts from Facebook and Twitter.

There are several studies that analyze this digital phenomenon in these kinds of entities. Most research studies focus on user behavior related to SDN and non-profit organizations (Castillo et al. 2014; Farrow and Yuan 2011; Wallace et al. 2017). Some works on the impact of SDN as effective marketing or communication tools have been carried out (Guo and Saxton 2014, 2018; Lovejoy and Saxton 2012; Soboleva et al. 2017). However, there is little evidence of the social media communication profiles of NGDOs in comparison with the public profile of social media communication. Hence, the interest in studying these profiles and the reaction from the public or interactions of the messages posted on Facebook and Twitter by NGDOs, in order to respond the following research questions:

What kind of messages, published by NGDO on Facebook and Twitter, cause a greater reaction from the public?

How can NGDO to increase the reaction from the public of their Facebook and Twitter messages through social marketing?

To answer these questions, the messages published by Caritas Asidonia Jerez (CAJ) and Cruz Roja Cadiz (CRC) on Facebook and Twitter, as well as the reaction from the public, have been analyzed. The reaction from the public refers to the interactions with the aforementioned social networks, and this has been measured by the sum of likes plus the number of shares for each post.

This analysis serves two goals. On the one hand, it serves to elaborate communication profiles from the points of view of the public and of the organizations, depending on the purpose (information, dialogue, and behavior), the theme, and the quality (format, hashtags, links, and mentions) of the message. On the other hand, it serves to analyze the reaction from the public (or interactions) of the messages according to the previous parameters. This will determine which are the appropriate social communication actions that produce the greatest impact on the messages. In other words, it is argued that the reaction from the public to publications in the aforementioned social networks depends on the purpose (information, dialogue, or behavior), the theme, and the quality (format, hashtags, links, and mentions).

The hypotheses have been tested based on the messages published on Facebook and Twitter during 2015 by CAJ and CRC. A total of 3608 posts were analyzed (1838 on Twitter and 1770 on Facebook). The results have shown several interesting facts. In most of the variables analyzed, the message communication profiles of the organizations do not coincide with the message communication profile of the public; that is, the types of messages most issued are not usually those that stimulate a greater reaction from the public, in the analyzed organizations. Also it is highlighted that hashtags, mentions, and links have very low levels of usage. Another point to note is the effectiveness of Twitter as 
a channel to transmit "call to action" or behavior messages rather than informative ones, which is usually the aim of microblogging. Finally, the phenomenon of "influencers" is important as a measure to increase the impact to the public in a very significant way. In this sense, it has been found that celebrity endorsements are effective, creating awareness for consistent prevention behaviors (Casais and Proença 2012).

With these results, this work aims to shed some light on the use of social networks (Facebook and Twitter) as social marketing tools in NGDOs.

\section{Theory Framework and Hypothesis Development}

\subsection{Social Marketing and Effectiveness}

Social marketing has been defined as being concerned with the application of marketing techniques and knowledge to enhance social objectives. The study carried out by Kotler and Zaltman in 1971 formally launched the social marketing field, and since then field has grown. A major advancement in the field came when researchers clarified that the end aim of a social marketing campaign is to encourage behavioral change in a specific target (Andreasen 1994; Dann 2010; Mckenzie-mohr and Schultz 2014; Saunders and Barrington 2015). Andreasen (1994) proposed the following definition:

"Social marketing is the adaptation of commercial marketing technologies to programs designed to influence the voluntary behavior of target audiences to improve their personal welfare and that of the society of which they are a part" (p. 110)

The distinctive characteristics of social marketing mean that it is difficult to measure results and to estimate the effectiveness (to the extent that the requirements of a given customer are met). There is little awareness of the benefits achieved. The behavioral factors, such as emotive elements, improved attitudes, knowledge, or perceived self-efficacy, may facilitate the end goal of social marketing, but do not provide sufficient evidence that social marketing interventions have achieved their stated purpose (Firestone et al. 2017; Parkinson et al. 2018). In other words, the goal definition and performance measurement is far more complex in non-profit organizations than in profit oriented firms. Among the factors that make it difficult to calculate the effectiveness of social marketing are the difficulty of choosing the target market due to the heterogeneity of audiences that NGDOs attend, a lack of marketing mentality at the levels of management, and difficulty in monitoring the results achieved from the campaigns (Helmig et al. 2004; Peattie and Peattie 2009).

Several models have been developed to analyze effectiveness in social marketing. For instance there is one model which helps social marketers account for industry involvement in the social or public health problem (Jones et al. 2017; Wymer 2017). Other research studies explore framing determinants in social marketing effectiveness (Firestone et al. 2017; Helmig and Thaler 2010), the impact of awareness campaigns (Bordarie 2019), the effectiveness of analysis of specific projects about health (Berends and Halliday 2018) and the environment (Soutter and Boag 2019).

With the emergence of the internet, social networks have become powerful communication tools. In the current digital environment, social media allows individuals to create, collaborate, and share content with one another. Non-profit organizations can realize social media's potential by incorporating it as part of the social marketing strategy. In this sense, a template for strategic thinking to successfully include social media as part of the social marketing strategy has been proposed (Thackeray et al. 2012). This is done by using a four step process: describe the audience; write down the purposes for wanting to engage with the audience; specify a strategy to engage the audience and accomplish the purposes identified; and choose the appropriate social media channel (Facebook, Twitter, etc.). Finally, the organization should outline a plan for how it will evaluate the success of its social media strategy in accomplishing its purposes. Possible metrics include measuring reach (e.g., followers), impressions (e.g., number of views, likes, visits), engagement (e.g., number of comments, downloads, sharing with others, or reviews posted), and sentiment analysis (comments, posts, tweets related to the behavior, program, or service). In this sense, there are several studies regarding sentiment 
analysis (Gomes and Casais 2018). In the analysis of non-governmental campaigns regarding anorexia nervosa, awareness through the content of comments and codifying of emojis expressing feelings from users is undertaken. Several studies analyze social media in non-profit organizations from the point of view of networks to explore relationships between organizations (Dong and Rim 2019; Ihm 2015; Lai et al. 2017). Other studies focus on analyzing the reactions of the public generated by each publication (likes, comments, and shares) by content analysis (Bellucci and Manetti 2017; Castellano and Folch 2018; Guo and Saxton 2014, 2018; Kite et al. 2016).

As discussed so far, in a digital scenario NGDOs should focus their efforts on understanding the use of SDN in order to achieve a greater reaction from the audience for major diffusion and visibility of the information.

\subsection{The Reaction from the Public or Interactions on Social Digital Network}

One of the objectives that NGDOs intend is for people to become involved with the organization and its cause. From this perspective, Hestres (2014) proposed a strategy that changed the vision of social marketing. He proposed that organizations should focus their efforts on understanding the use of SDN instead of using most of the resources to achieve a change in behavior. This suggests the possibility of offering interesting content to the public that would favor a greater diffusion and visibility of the information. In the end, organizations must work to determine how to transform their supporters into vocal promoters of their causes (Bernhardt et al. 2012). In the same lines of research are the studies of Dooley et al. (2012) and Kotler (2011), who showed that social marketing can go beyond creating awareness and changing behaviors. This new step involves the vocal mobilization of your target audience. This means that NGOs must get users to talk about social causes through their social networks, and thus get the information they disseminate to become viral.

According to everything read so far, it can be affirmed that Facebook and Twitter are two appropriate tools to create relationships and mobilize the public, thanks to their ability to generate conversation and exchange information. Given this fact, the NGDOs must be especially methodical in measuring the results of communication activities in SDN; that is, they must be very clear about the keys to evaluate the proper functioning of the marketing strategy.

The communication actions of the organizations have an immediate response in the online environment through the shared links, comments, and times that the messages are "liked" (Pulido et al. 2018). These aspects are part of other more complicated concepts to measure, called qualitative variables, such as conversation, trust, influence, engagement, prescription, participation, credibility, or other indicators (Lamas 2010). In this way, the term of the social ROI or Impact On Relationship (IOR) appears. This ratio measures profitability through the relationships between the brand and its followers. This nexus is computed through four variables: the content authority (related to the mentions of the brand outside their profiles); the influence (number of followers in social media); the participation (comments, retweets, etc.); and the traffic (Cavalcanti and Sobejano 2011).

Another way to measure the success of SDN would be to consider the size of the community (which is measured by the number of fans or followers of a Twitter or Facebook account), the level of activity (measured by the impact of the contents that are published and shared), and the qualified traffic (flow that reaches the web from SDN (Chung 2017; Guo and Saxton 2018; Macia and Gosende 2011; Moonhee and Boatwright 2019).

Regarding the metrics specified in previous lines, there are three that are linked to each post that make them more appropriate for the analysis of the effectiveness of the message. Moreover, these indicators demonstrate the willingness of the person to become a defender and promoter of the organization's messages (Saxton and Waters 2014). These metrics are:

1. The number of responses or comments from fans;

2. The actions associated with each message, such as the number of favorite messages, or "likes";

3. The number of times a publication has been shared. 
In the case of NGDOs, the analysis of the indicators mentioned above could offer information on how to establish guidelines that serve to improve and optimize the online strategies (Soria 2014). This is intended to mobilize the community in order to make their voices amplified and to create a real systematic social change. They would also motivate the latent target (individuals who face a similar problem but they are not aware of it) and conscious target (people who are affected by a similar problem and recognize it) so that they are more receptive to the messages published (Grunig and Hunt 2000; Naik and Peters 2009). There are several works that analyze social media effectiveness, among which some stand out (Fernandez et al. 2017; Guidry et al. 2014; Guo and Saxton 2014; Hoover et al. 2018; Lucas 2017; Saxton and Waters 2014; Williams et al. 2015). To know how NGODs should use social media effectively, specifically Facebook and Twitter, it is necessary to analyze the impact of these SDNs, in order to determine the key points that encourage a greater reaction of the target audience. This can be done by measuring whether the public is more or less a promoter of the message through variables, such as "Like" and "Shared", a phenomenon called the bandwagon effect. This expression means that people in general blindly rely on the collective opinions of others without an adequate evaluation of their own opinions (Sundar 2008).

The process to analyze the effectiveness of Facebook and Twitter will be carried out from two points of view. The first one studies the messages published by these organizations according to three parameters: purpose, theme, and quality. The second one analyzes the public reaction to the communicative actions in these publications. This approach is summarized in Figure 1.

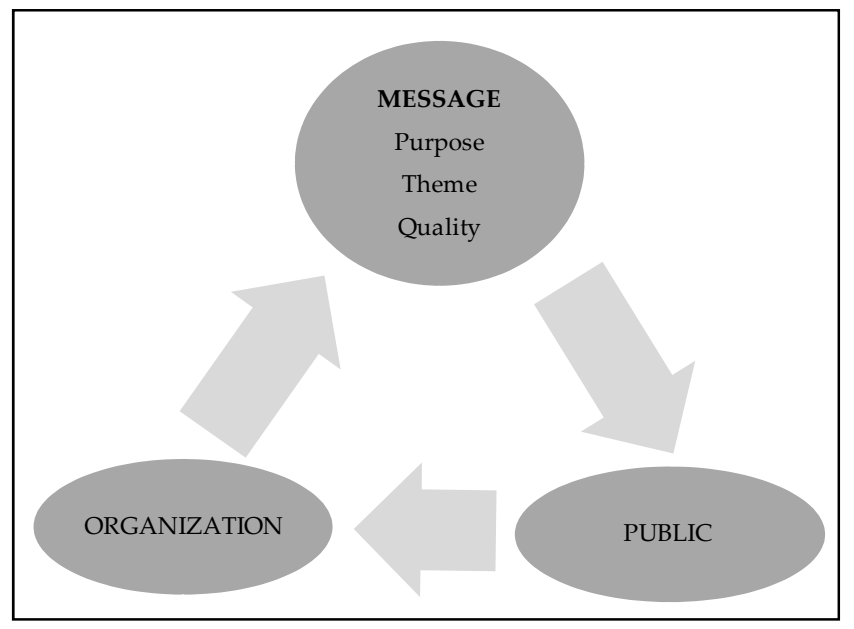

Figure 1. Public approach for message analysis.

Based on this approach, we propose the hypotheses specified in the following section.

\subsection{The Purpose of the Message}

NGDOs in general are prone to using SDNs as traditional advertising channels, which implies that they are mere promoters of their actions. This would mean that they do not take advantage of the opportunity offered by SDNs to encourage online dialogue (Ramil 2012). This assumption is fully in-line with Arroyo et al. (2012) approach, who affirm that NGDOs tell the public what they do or what they do not do in the messages, emphasizing the presence of anonymous protagonists who relate their experience in first person. In the end, the organizations publish informative messages, not attractive ones that catch attention. In this sense, Iranzo and Farné (2014) and García de Torres et al. (2011) classify messages according to a dimension called "participative axis" into two categories: referential, or conversational. Referential messages simply offers information, while conversational messages encourage reactions from the audience. Other similar classifications were carried out by Guo and Saxton (2014) and Guidry et al. (2014). According to these studies, the messages are classified as informative, conversational, or action. The category one is divided into 
two types-one is called "public education", which represents information regarding possible changes in public policies to improve the interests of citizens, and the other is called "marketing", which means having an emotional tone. According to the previous researchers, public education messages generate more impact. These messages are called informative messages, or "shoveling tweets", characterized because they are sent indiscriminately and without consideration on how followers could respond to them (Messner et al. 2012).

At this point it is necessary to note that not many academic papers have explored informative messages analysis. This is maybe because of the complexity of establishing common classification criteria for the large list of existing NGDOs. Hence, the relevance of this work is to analyze this aspect. To carry this out, we divide informative messages into two categories-one related to the information about the organization (assemblies, etc.), and the other regarding general social information (such as human rights or sustainable development goals, among others).

Continuing with the explanation, it should be noted that the NGDOs should develop relationships based on mutual trust and transparency. On this point, Muñoz (2015) indicates that it is necessary to view communication as a dialogue, that is, to be more conversational than informative. This requires a favorable environment for participation to encourage the interaction with individuals with diverse opinions, thus cultivating trust between the parties (Kent and Taylor 2002). In order to achieve this goal, easily navigable and attractive online platforms are needed with useful information. Basically, this all encourages users to do two things: firstly to return to the platform, and secondly to start conversations.

From this approach, social media provides adequate channels to promote dialogue, especially on Twitter and Facebook. However, it should be noted that an interesting platform is not enough if it is not accompanied by communicators willing to create a greater commitment to their fans and followers (Carrigan and Dibb 2013). To achieve this goal in this article, we have considered classifying messages that generate conversation into three categories: recognition, gratitude, and question. In this way, a positive and favorable attitude toward the organization is fostered (Lovejoy and Saxton 2012; Nelson 2019).

In addition to cultivating relationships between organizations and the audience, Lovejoy and Saxton proposed another type of post, called a "call to action" message, which encourages collaboration and promotes users from being informed members to being an active part. These messages are divided into the following categories: promotion of events, fundraising, sale of a product, call to volunteers or employees, support for aid, and support for the organization in other indirect forms of donation. Two years later Guidry et al. (2014) titled these kinds of publications as "promotion", which are subdivided into three subclasses: calls to action, events, and fundraising. Furthermore, we also note that the aforementioned investigation determined the existence of two phenomena. The first was that it was not likely that the fundraising and event messages would be retweeted or qualified as favorites. The second was that there was a considerable possibility that the messages of "calls to action" were shared by the users. Based on the previous premises, the following hypothesis arises.

Hypothesis 1. The purpose of the message (information, dialogue, behavior) influences the public's reaction, both on Twitter and Facebook.

\subsection{The Theme of the Message}

Regarding the themes that NGDOs refer to in their messages on social networks, it should be noted that there is a certain complexity in establishing common classification criteria, due to the extensive list of existing organizations. In general, the main areas where NGODs are working are education, health, gender, governance, and human rights (Coordinadora de ONGD España 2017). Currently, organizations have to take their Sustainable Development Goals (SDG) into account. Sustainable Development Goals are the blueprint for achieving a better and more sustainable future for all. They address the global challenges we face, including those related to poverty, inequality, climate, environmental degradation, prosperity, and peace and justice. With regard to SDGs, one of the main 
problems is the special needs of people living in areas affected by complex humanitarian emergencies and in areas affected by terrorism or catastrophe.

In-line with this comments, the contributions of several studies suggest that the messages related to emergencies (which require rapid mobilization of the public) could constitute an important group of messages (Saiz and Mantini 2012). As the aforementioned authors point out, this phenomenon emerges because an empathic identification with the situation occurs automatically. Therefore, advertising has to involve almost no argument to persuade the recipients; it simply has to focus effort on attracting attention and offering useful and clear information to facilitate the collecting of human and economic resources. Another interesting contribution on this issue shows that the messages of the NGDOs do not inform about the causes generated by situations of inequality thoroughly (Lucerga 2013).

Taking this into account, as well as the information provided by the communication managers and the review of the analyzed messages, the publications will be classified according to the thematic variables in the following categories: poverty and social exclusion; employment; international cooperation; religion or spiritual; institutional; and resources revitalization (see methodology). The hypothesis that arises in this regard is the following.

Hypothesis 2. The reaction of the public is different depending on the theme of the message, both on Twitter and Facebook.

\subsection{The Quality of the Message}

It is a fact that the messages must be adapted to the language of social networks. To this end, it is necessary to keep in mind the creativity and innovation in the contents with the purpose of reaching the public more effectively. This can be carried out through the generation of striking new close and modern designs, and new visual formats that facilitate the understanding of the messages (Arroyo et al. 2013). The multimedia format, such as text, images, photos, videos, or a combination of these resources, facilitates the understanding of the messages (Burton and Soboleva 2011). At the same time this makes the content viral and encourages people to participate and share their own experiences, creating hashtags to share the social cause (Baamonde et al. 2015).

According to Arroyo et al. (2012), photos have more impact than videos and text on Facebook, the most popular medium for showing photographs. Regarding this statement, Soria (2014) has another opinion-unlike Twitter, Facebook allows us to show audiovisual material in a much clearer and more visual way. This means that the NGDOs opt for this social network to include their graphic information.

In line with the comments above, the emission of attractive messages does not mean that the audience will read the messages, or even that they will interact and give their opinion in the conversations. Burton and Soboleva (2011) stated that this interactivity could be promoted with a greater understanding of information thanks to the presence of features such as links or hyperlinks, hashtags, or mentions. The analysis of these parameters can provide relevant information if they are related to the reaction of the public, so it is relevant to explore these elements that contribute to the quality of the publication. In this sense, we propose the following hypotheses.

Hypothesis 3. The reaction of the public is different depending on the type of format used in the messages, both on Twitter and Facebook.

Hypothesis 4. The number of mentions and hashtags influences the reaction of the public, both on Twitter and Facebook.

Hypothesis 5. The reaction of the public depends on the link in each message, both on Facebook and Twitter. 


\section{Materials and Methods}

\subsection{Non-Govermental Development Organizations and Selection of Social Media}

In order to carry out the research, the NGDOs CAJ and CRC, which have the largest number of delegations in the province of Cadiz, have been considered. Also, these organizations are registered in the Spanish Development Cooperation Agency (AECID), the main cooperative management body in Spain oriented towards the eradication of poverty and sustainable human development. To be registered in AECID is a guarantee of operating transparency, since the organization's partners are obligated to verify the suitability as well as the veracity and authenticity of the registered information. In addition, both Caritas and Red Cross are part of the organizations named by the AECID as "qualified", that is, they have passed an accreditation process that certifies their experience and capacity.

The social media selected are Facebook and Twitter, two of the most popular social networks in Spain, as shown in the IAB Spain reports from 2008 to 2018, a period in which the percentage of users of the RSD grew from $51 \%$ to $85 \%$. According to this study, the most popular SDNs are Facebook, Twitter, and Instagram.

From the information mentioned above, it could be deduced that SDNs have become an extended phenomenon that has not gone unnoticed by NGDOs. They consider them an instrument to develop their marketing activities. In this sense, the study conducted by del Mar Soria (Soria 2013) revealed that $70 \%$ of the NGOs surveyed use the Internet as media support for their marketing activities. To be more concise on this subject, it is noteworthy that the NGDOs belonging to the NGO Coordinator of Spain Development currently have a Facebook profile or a Twitter account.

\subsection{Investigation Approach and Information Gathering Techniques}

In this study, a descriptive approach was employed. A content analysis was carried out from a qualitative and quantitative perspective (Landry 1998). This type of analysis is appropriate for large volumes of information to encode the various elements of the messages into categories and find patterns that give meaning to communication (Arroyo et al. 2009; Krippendorff 1990). In this way the communication profiles of the messages were elaborated from the perspectives of the organization and the public. Afterwards, a correlational analysis was performed to relate the dependent variable, reaction of the public, with the independent variables: purpose, theme, format, hashtags, links, and mentions.

To carry out the content analysis the approach of Bardin was taken into consideration, which presents the following three steps: pre-analysis, material exploration, and treatment of the results (Bardin 1983).

\subsubsection{Pre-Analysis: Identification of the Sample and Variables}

The first stage of the process is to identify the units of analysis, as well as the variables to be examined. Following this first step, 1078 messages on Twitter and 622 ones on Facebook for CRC, and 760 messages on Twitter and 1148 ones on Facebook for CAJ were identified as study units, making a total of 3608 posts published in 2015.

To encode the variables, numerical indicators or categories were specified according to the categorical or numerical variables. The variable activity (variable 1) is the number of emitted messages, and the variable public reaction (variable 2) is the sum of the number of shares plus likes in each post.

In relation to the purpose of the message (variable 3), the studies of García de Torres et al. (2011), Iranzo and Farné (2014), Lovejoy and Saxton (2012), and Guo and Saxton (2014) were taken into consideration. Based on these studies, the messages were classified as the following: informative, dialogue, and behavior. After exploring a little further, and after an exhaustive review of the publications, it was decided to create another classification for the information: dialogue and behavior messages. Information (variable 4): organization (organizational, legislative aspects, etc.) and social issues (human rights, sustainable development objectives, etc.). Dialogue (variable 5): gratitude, 
recognition (of organization work or its partners and voluntary workers and helpers) and questions. Behavior (variable 6, they invite action): events (with words like "come", "do not miss", etc.) and collaboration (with all the information necessary to donate, such as the account number, or to improve the visibility of the network).

The following variables have been considered for the dimension quality of the message. Variable format (variable 7): text; text and photo; text and image; text and video; image, photo, and video. Moreover, the link (variable 8) has also been taken into account, with the categories "with link" or "without link", and finally the numerical variables mentions (variable 9) and hashtags (variable 10), which have been selected for their importance in the impact of the messages, as they has been verified in diverse studies (Martín 2010; Moll 2015; Zhang 2010).

The variable theme (variable 11) refers to the social topics mentioned in the message: poverty and social exclusion, employment, international cooperation, religion or spiritual, institutional (organizational management issues), and resources revitalization (topics of interest such as human rights, economy, etc.)

To find out the most appropriate categories of the variable theme, the communication leaders in CRC and CAJ were interviewed, with the purpose of knowing the subjects that, in their opinions, are the most indicative for sorting the messages. Once the interview was done and after examining the database, the next step was to consult two experts in NGDOs. We sent a sample of 100 randomly chosen publications from Facebook and Twitter to them by mail, to be cataloged into a proposal of provisional categories. In order to decide if these categories were going to be selected, it was necessary to check the agreement between the classifications made by the two experts. As a measure of this, Cohen's kappa coefficient (Table 1) was used (Warrens 2011).

Table 1. Kappa coefficient results for variable theme.

\begin{tabular}{|c|c|c|c|c|}
\hline & Value & Asymp. Std. Error a & Approx. $T^{b}$ & Approx. Sig. \\
\hline $\begin{array}{c}\text { Measure of Agreement Kappa } \\
\text { N of Valid Cases }\end{array}$ & $\begin{array}{c}0.709 \\
100\end{array}$ & 0.052 & 16.379 & 0.000 \\
\hline
\end{tabular}

Source. Own elaboration. ${ }^{a}$ Not assuming the null hypothesis; ${ }^{b}$ Using the asymptocic standard error assuming the null hypothesis.

The kappa coefficient value is 0.709 , which indicates that the agreement between the two coders is satisfactory according to the scale of the aforementioned researcher. On the other hand, the level of significance, less than 0.05 , indicates that the correlation between the two classifications is accepted (the null hypothesis, that there is no agreement between the results of the two experts, and is rejected). Therefore, the theme variable was codified according to the following categories: poverty and social exclusion, employment, international cooperation, religion or spiritual, institutional (organizational management issues), and resources revitalization (topics of interest, such as human rights, economy, etc.)

\subsubsection{Data Extraction and Information Analysis}

Data extraction is the second stage in the process of content analysis. To this end, we have worked with two tools available at the following links: www.twitonomy.com and www.audiense.com (for Twitter), and Netvizz (for Facebook), as well as the official pages of both social media (www. Twitter.com and www.Facebook.com).

Once the data was extracted, the messages were encoded according to the specified variables. Following the methodological process of content analysis, the third stage is the analysis of the information extracted in order to provide statistically meaningful information about each parameter considered that support the decision making regarding social communication actions. The resource used for this was the SPSS program, which allows two types of analysis, one descriptive and another correlational. The correlational type of analysis is carried out with the purpose of considering the correlation between the dependent variable — the reaction of the public-and the independent 
variables-purpose, theme, format, hashtags, mentions, and links. Such correlations will be supported in the hypotheses, tested through the non-parametric Kruskal Wallis (K-W) test and the Pearson correlation coefficient, as the case may be appropriated.

\section{Results and Discussion}

The general results of the descriptive analysis about the percentage of messages published and the average reaction from the public on Twitter and Facebook are presented below, in Figure 2 and Table 2.

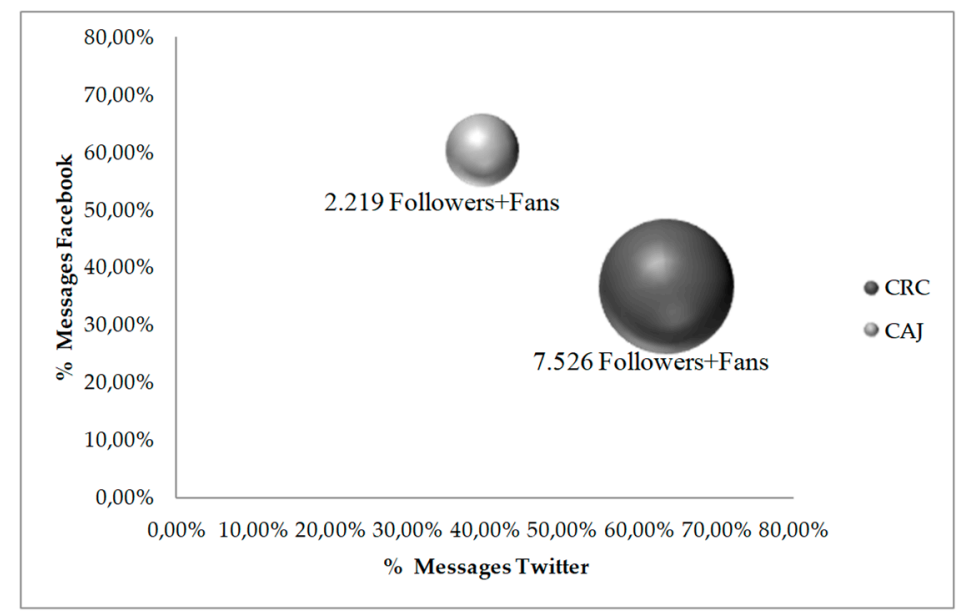

Figure 2. Messages published on Facebook and Twitter by CRC and CAJ during 2015.

Table 2. Average public reactions for Twitter and Facebook for CRC and CAJ.

\begin{tabular}{ccc}
\hline NGDO & Twitter Average Public Reaction & Facebook Average Public Reaction \\
\hline Cruz Roja Cadiz & 2524 & 3167 \\
Caritas Asidonina Jerez & 68,872 & 698 \\
\hline
\end{tabular}

The results of Figure 2 show that on the one hand, the volume of messages published on Facebook by CAJ $(60.17 \%)$ is greater than by CRC $(36.59 \%)$, and on the on the other hand, the volume of posts on Twitter by CAJ $(39.83 \%)$ is smaller than by CRC (63.41\%).

If we take into consideration the average public reaction of the social networks analyzed, an important difference can be noted for Twitter, as shown in Table 2.

In Table 2, a very high average public reaction can be observed for the CAJ Twitter handle @CaritasJerez $(68,872)$ in comparison with the average public reaction for the CRC Twitter handle @CruzRojaCA (2524). This phenomenon is due to messages from the user @Pontifex_es (official Twitter of His Holiness Pope Francis), which have been retweeted by @CruzRojaCA. The most popular post is shown in Figure 3.

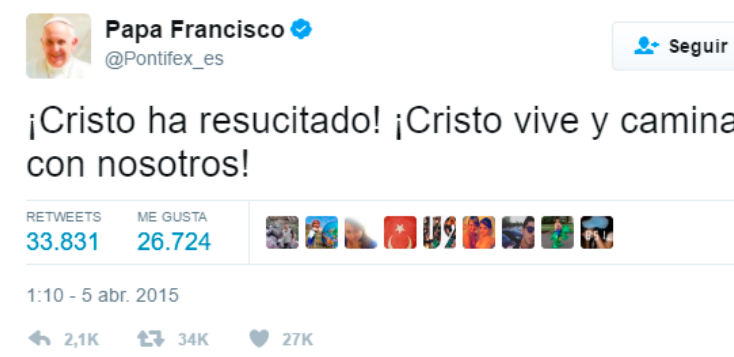

Figure 3. The retweet published by @CaritasJerez on 5 April 2015. Available at https://Twitter.com/ Pontifex_es/status/584629104000933889. 
The message shown in Figure 3 has been shared 33,831 times and has 26,724 likes. It transmits religious information, but the most important thing is the user who relates it, his Holiness Pope Francis, since the publications written by this user have the greatest impact on Twitter during the period considered. If we did not take these messages into account, the average number of reactions per post on Twitter would be 3041, a much lower figure than the impact reported in Table $2(68,872)$.

The following findings are presented so as to know how to get the public to become a vocal defender of social causes.

Firstly, Facebook and Twitter communication profiles, from the point of view of the organization and the public, are exposed according to each variable considered (purpose, informative messages, dialogue messages, behavior messages, theme, format, links, hashtags, and mentions). To carry out communication profiles from the point of view of the organization, the number of posts published in Facebook and Twitter are considered. From the point of view of the public, the average public reaction is considered. In this way it is possible to check if the most published messages, according to each variable, are those that have had the greatest reaction from the public.

Secondly, the testing of the hypotheses was advanced in order to verify which aspects provoke a greater reaction in the public in the organizations analyzed.

\subsection{The Purpose of the Message}

In this section, communication profiles are analyzed according to the purpose of the messages, both from the point of view of the organization and the public. On the one hand, the profile of the organization is indicated by the activity, represented by the number of messages published according to the purpose considered. On the other hand, the average reaction of the public according to each type of purpose (informative, dialogue, and behavioral) is shown. Figure 4 shows these profiles on Facebook and Twitter for CRC.
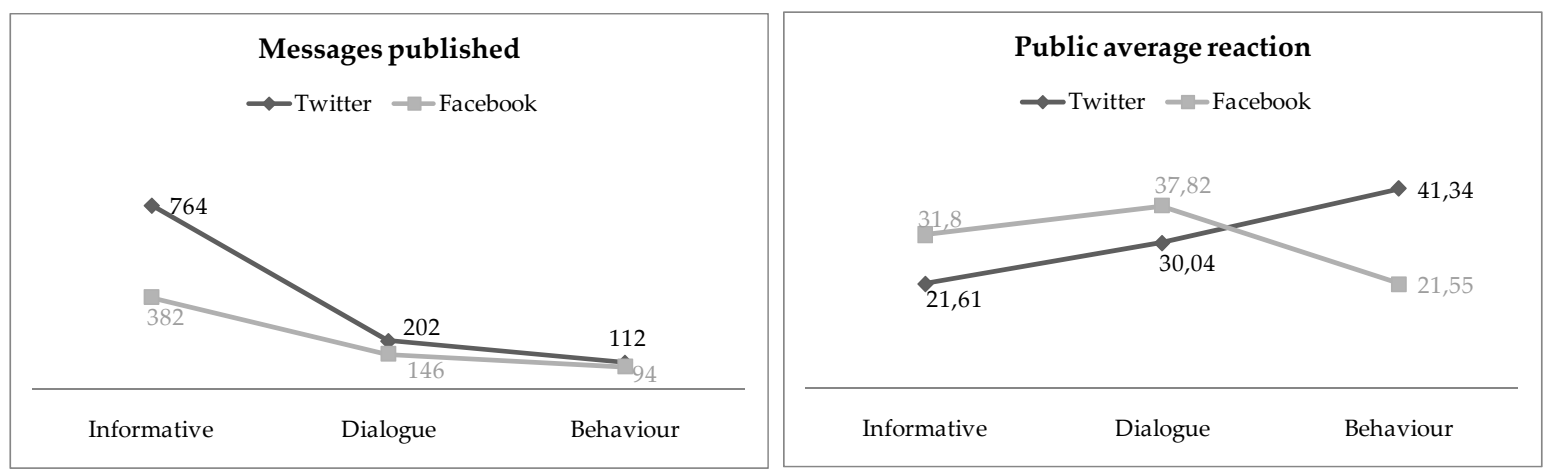

Figure 4. The purposes of messages on Twitter and Facebook for CRC (2015).

In Figure 4, two facts can be observed on Twitter. On the one hand, the behavior messages provoke the greatest reaction from the public, even though they are the least published. On the other hand, the informative messages are the most published, even though they have the least reaction. In relation to Facebook, the lowest response capacity is generated by behavioral messages coinciding with the type of publications that are least published. Furthermore, the greatest reaction from the public on Facebook is related to dialogue messages, even though the informative messages are the most published.

Following these result highlights the fact that Twitter is a channel that is not only used to inform, but is also effective for behavioral messages, specifically those that incite economic collaboration or participation in events. This data is striking because in microblogging it is unusual to write call-to-action messages to increase the visibility of the page (press like) or to attend an event, since they require comprehensive information on how to collaborate monetarily.

Below are the communication profiles, according to the purpose of the message, by CAJ.

Figure 5 shows that the majority of messages published and also the most effective are informative ones (except on Facebook, where the reaction is greater in the behavioral posts). It is observed that the 
greatest difference is between informative messages and posts of dialogue and behavior, due to the disproportionate reactions that the messages of Pope Francis have caused.
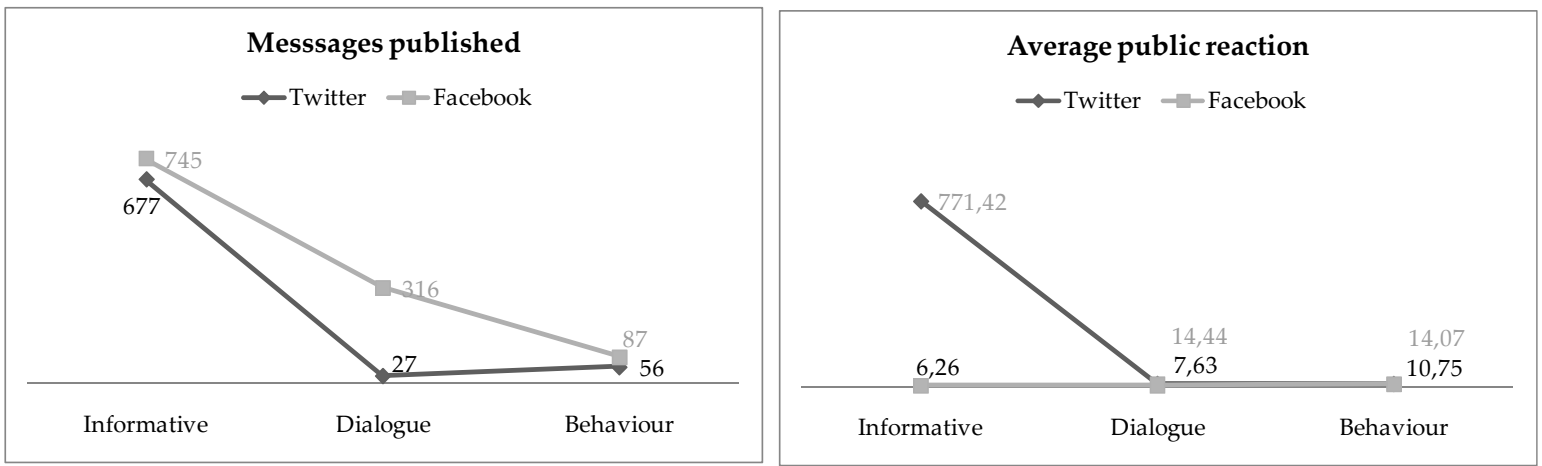

Figure 5. Profiles according to the purpose of the message on Twitter and Facebook of CAJ (2015).

After examining the communication profiles of the organization, we proceed to test Hypothesis 1: The purpose of the message influences the public's reaction, both on Twitter and on Facebook. In order to test this hypothesis, the K-W test was used.

The results show a level of significance $p<0.05$ in CRC and CAJ, both on Facebook and Twitter. Therefore, it is concluded that the reaction of the public depends on the purpose of the message in both social media and in the two organizations analyzed. A summary of the hypothesis can be consulted in Appendix A.

From studying each purpose more closely, we obtain the following summary tables (Table 3 , Table 4).

Table 3. Communication profiles of NGDOs according to informative messages.

\begin{tabular}{ccccc}
\hline & \multicolumn{2}{c}{ Twitter-informative } & \multicolumn{2}{c}{ Facebook-informative } \\
\hline NGDO & Messages published & $\begin{array}{c}\text { Public average } \\
\text { reaction }\end{array}$ & Messages published & $\begin{array}{c}\text { Public average } \\
\text { reaction }\end{array}$ \\
\hline CRC & $\begin{array}{c}\text { Information about } \\
\text { organization } \\
(76.96 \%)\end{array}$ & $\begin{array}{c}\text { Information about } \\
\text { social issues } \\
(29.96)\end{array}$ & $\begin{array}{c}\text { Information about } \\
\text { organization } \\
(74.87 \%)\end{array}$ & $\begin{array}{c}\text { Information about } \\
\text { organization } \\
(36.15)\end{array}$ \\
\hline CAJ & $\begin{array}{c}\text { Information about } \\
\text { social issues } \\
(77.25 \%)\end{array}$ & $\begin{array}{c}\text { Information about } \\
\text { social issues } \\
(994.80)\end{array}$ & $\begin{array}{c}\text { Information about } \\
\text { organization } \\
(72.35 \%)\end{array}$ & $\begin{array}{c}\text { Information about } \\
\text { organization } \\
(8.70)\end{array}$ \\
\hline
\end{tabular}

Table 4. Communication profiles of NGDOs according to dialogue messages.

\begin{tabular}{ccccc}
\hline & \multicolumn{2}{c}{ Twitter-dialogue } & \multicolumn{2}{c}{ Facebook-dialogue } \\
\hline \multirow{2}{*}{ NGDO } & Messages published & $\begin{array}{c}\text { Public average } \\
\text { reaction }\end{array}$ & Messages published & $\begin{array}{c}\text { Public average } \\
\text { reaction }\end{array}$ \\
\hline \multirow{2}{*}{ CRC } & Recognition & Recognition & Recognition & $\begin{array}{c}\text { Question } \\
(53.18)\end{array}$ \\
\hline \multirow{2}{*}{ CAJ } & $(47.46 \%)$ & $(43.48)$ & $(43.15 \%)$ & Gratitude \\
& Recognition & Gratitude & Recognition & $(16.00)$ \\
\hline
\end{tabular}

Source. Own elaboration.

In the case of Twitter, the marked religious nature of CAJ stands out. The messages with this nuance were cataloged into the category of social issues and for this category the organization communication profile of the informative messages coincides with the public communication profile, because this type 
of messaging is the most published and has the highest public reaction. Likewise, the disproportionate reaction of the public for CAJ was motivated by the messages of His Holiness Pope Francis, as mentioned previously. This fact shows that the importance of a user, their profession, prestige, trust, etc., is crucial for building responsiveness in the audience. In relation to the type of dialogue or conversational messages, only on the CRC Twitter account does the organization's communication profile coincide with the public communication profile (Table 5). In this case, the messages of work recognition are the most published, and also have the greatest impact.

Table 5. Communication profiles of NGDOs according to behavioral messages.

\begin{tabular}{ccccc}
\hline & \multicolumn{2}{c}{ Twitter-behaviour } & \multicolumn{2}{c}{ Facebook-behaviour } \\
\hline \multirow{2}{*}{ NGDO } & Messages published & $\begin{array}{c}\text { Public average } \\
\text { reaction }\end{array}$ & Messages published & $\begin{array}{c}\text { Public average } \\
\text { reaction }\end{array}$ \\
\hline \multirow{2}{*}{ CRC } & Event & Colaboration & Event & Event \\
& $(78.57 \%)$ & $(82.58)$ & $(70.21 \%)$ & $(23.36)$ \\
\hline \multirow{2}{*}{ CAJ } & Event & Colaboration & Event & Event \\
& $(73.21 \%)$ & $(46.80)$ & $(74.71 \%)$ & $(11.48)$ \\
\hline
\end{tabular}

Source. Own elaboration.

Likewise, in the case of Facebook, the high impact of question-type messages is worth nothing. The reason this is significant is because this channel fosters social relations through the conversation. The most effective publication is dated July 13,2015, and it refers to an older person enjoying a walk on the beach thanks to the help of volunteers. It encourages dialogue, as indicated by the question that can be read, "Does this comment deserve a 'Like'?"

Finally, in the case of behavioral messages, the most remarkable fact is on Facebook in both organizations, where the organization communication profiles coincide with public communication profiles. In this social network, publications about events are the most broadcast. They are also those that provoke the most reaction from the public.

\subsection{The Theme of the Message}

The topics that are part of the content of the publications on Facebook and Twitter constitute an indicator of people's social concerns, as well as the activities and projects carried out by the NGDOs. Table 6 presents the topics that organizations publish the most and those that encourage a greater reaction in the public.

Table 6. The communication profiles of the NGDOs analyzed according to theme.

\begin{tabular}{|c|c|c|c|c|}
\hline \multirow[b]{2}{*}{ NGDO } & \multicolumn{2}{|c|}{ Twitter-theme } & \multicolumn{2}{|c|}{ Facebook-theme } \\
\hline & Messages published & $\begin{array}{l}\text { Public average } \\
\text { reaction }\end{array}$ & Messages published & $\begin{array}{l}\text { Public average } \\
\text { reaction }\end{array}$ \\
\hline CRC & $\begin{array}{l}\text { Poverty and social } \\
\text { exclusion } \\
(20.78 \%)\end{array}$ & $\begin{array}{c}\text { Emergencies } \\
(38.34)\end{array}$ & $\begin{array}{c}\text { Poverty and social } \\
\text { exclusion } \\
(30.78 \%)\end{array}$ & $\begin{array}{l}\text { Prevention } \\
\quad(44.09)\end{array}$ \\
\hline CAJ & $\begin{array}{l}\text { Poverty and social } \\
\text { exclusion } \\
(30.39 \%)\end{array}$ & $\begin{array}{l}\text { Religion or } \\
\text { spiritual } \\
(3040.28)\end{array}$ & $\begin{array}{l}\text { Religion or } \\
\text { spiritual } \\
(30.92 \%)\end{array}$ & $\begin{array}{c}\text { Emergencies } \\
(11.29)\end{array}$ \\
\hline
\end{tabular}

Source. Own elaboration.

As indicated in Table 6, the themes published in the messages do not coincide with those with the greatest impact on the public, that is, the organization communication profile according to the theme do not coincide with the public communication profile in the organizations analyzed.

A highlight of the results obtained through this research is that poverty and social exclusion is the most published topic group. This phenomenon coincides, on the one hand, with one of the most 
worrying issues in Spain (Antevenio 2016), and on the other, with the area most selected by people to participate in volunteering (PVE 2016).

Another significant fact that has been deduced in this scientific study is that the themes that interest the public are different (both on Facebook and on Twitter) in both organizations considered. In the case of Facebook for CRC, the greatest reaction from the public has been on prevention issues. This is not the case for CAJ, due to two fundamental facts. The first is that CRC has risk and emergency management equipment to assist and ensure the safety of events. The second is the importance in this organization of talking about cultural, sports, or leisure initiatives that take place in nearby towns (carnivals, Holy Week, fairs, etc.). In these events, volunteers are present, and one of the fundamental concerns of CRC is to recognize their work. However, at CAJ, volunteers are not mentioned frequently. In this latter organization, the fact that most of the messages published are religious is highlighted. One final point to note is that the issue of emergencies is important for the audiences in the organizations analyzed. This significance is caused due to people's identification with the plight of victims (Veer et al. 2015).

At this point, the next step is to verify the importance of the different themes in the public reaction, through Hypothesis 2: The reaction of the public is different depending on the theme of the message, both on Twitter and Facebook. When comparing this hypothesis in both Twitter and Facebook, for the level of significance corresponding to the $\mathrm{K}-\mathrm{W}$ test in the cases analyzed, the $p$ value is less than 0.05. Therefore, we accept the hypothesis that the theme influences the reaction of the public, both on Facebook and Twitter in the two organizations analyzed.

\subsection{The Quality of the Message}

The quality of the message, understood as those aspects that make it understandable and facilitate access to information, is a matter to be taken into account. In Table 7, the main results are compiled.

Table 7. The communication profiles of the NGDOs analyzed according to the format, links, hashtags, and mentions.

\begin{tabular}{|c|c|c|c|c|}
\hline \multirow[b]{2}{*}{ NGDO } & \multicolumn{2}{|c|}{ Twitter-Quality } & \multicolumn{2}{|c|}{ Facebook-Quality } \\
\hline & Messages published & $\begin{array}{c}\text { Public average } \\
\text { reaction }\end{array}$ & Messages published & $\begin{array}{c}\text { Public average } \\
\text { reaction }\end{array}$ \\
\hline CRC & $\begin{array}{c}\text { Text and photo } \\
(41.56 \%) \\
\text { No link }(81.45 \%) \\
\text { One hashtag } \\
(43.04 \%) \\
\text { No mentions } \\
(84.87 \%)\end{array}$ & $\begin{array}{c}\text { Text and photo } \\
(29.71) \\
\text { Link }(33.06) \\
\text { One hashtag } \\
(34.81) \\
\text { No mentions } \\
(29.60)\end{array}$ & $\begin{array}{c}\text { Text and photo } \\
(57.55 \%) \\
\text { No link }(73.63 \%) \\
\text { No hashtag } \\
(73.47 \%) \\
\text { No mentions } \\
(99.36 \%)\end{array}$ & $\begin{array}{c}\text { Text and video } \\
(38.42) \\
\text { No link }(34.99) \\
4 \text { hashtags }(45.00) \\
\text { No menions }(31.76)\end{array}$ \\
\hline CAJ & $\begin{array}{c}\text { Text }(71.05 \%) \\
\text { No link }(44.74 \%) \\
\text { No hashtag }(66.18 \%) \\
\text { No mentions } \\
(84.87 \%)\end{array}$ & $\begin{array}{c}\text { Text }(960.24) \\
\text { No link }(1511.25) \\
\text { No hashtag } \\
(937.71) \\
\text { No mentions } \\
(805.58)\end{array}$ & $\begin{array}{c}\text { Text }(43.73 \%) \\
\text { No link }(49.65 \%) \\
\text { No hashtag } \\
(95.85 \%) \\
\text { No mentions } \\
(98.87 \%)\end{array}$ & $\begin{array}{c}\text { Video }(39.00) \\
\text { No link }(8.31) \\
\text { No hashtag }(7.08) \\
2 \text { mentions }(20.00)\end{array}$ \\
\hline
\end{tabular}

Source. Own elaboration.

In relation to the data in Table 7, it is noted that the organizations' communication profiles coincide with the public communication ones on Twitter for CAJ and CRC, except for the variable "links". In the case of Facebook, there is not much correlation.

Two other issues to be highlighted are the following. First, the format with text and photo is the most effective on Twitter for CRC, and second, video acquires special prominence on Facebook in both organizations. One of the reasons for this fact is the Christmas concert video that CAJ published, which got the highest average public reaction per message.

At this point it is appropriate to discuss Hypothesis 3: The reaction of the public is different depending on the format used in the messages, both on Twitter and Facebook. This hypothesis 
is proven for CRC on Facebook and Twitter. Tt is also proven on Facebook for CAJ, but for this organization it is not confirmed on Twitter. One of the factors that influenced this fact is that CAJ's impact on Twitter was due to the messages that they shared from Pope Francis that went viral.

With reference to the variable "link", it has been observed that messages published without this resource predominate both on Facebook and Twitter in both organizations, and also they have the higher public reaction (except in Twitter of CRC). The link is not a resource that is widely used or that encourages public reaction. This fact could be improved if the publications had more content regarding the reasons for social events; that is to say, to report more on the causes rather than on the consequences. This demonstrates that organizations speak too much about themselves or about actions they carry out.

A similar result was obtained in relation to the number of hashtags. In this case, most messages are issued without this resource. Also, the analysis shows that the most popular messages are those that contain four hashtags in CRC postings on Facebook.

Finally, in relation to the number of mentions, the analyzed organizations opted mostly to issue publications without this resource on Facebook and Twitter. The reaction of the public was similar for CRC on Facebook and Twitter, but for CAJ the most effective messages were those with two mentions.

In relation to the above, it is necessary to remember the hypothesis stated below.

Hypothesis 4. The number of mentions and hashtags influences the reaction of the public, both on Twitter and Facebook.

To test H4, the Pearson correlation coefficient was calculated. The results are shown in Tables 8-11.

Table 8. Correlation for hashtags and mentions forCRC on Twitter.

\begin{tabular}{|c|c|c|c|c|}
\hline & & Correlations $^{a}$ & & \\
\hline \multirow{4}{*}{$\mathrm{N}^{\circ}$ hashtags } & & $\mathrm{N}^{\circ}$ hashtags & Public reaction & $\mathrm{N}^{\mathrm{o}}$ mentions \\
\hline & Pearson Correlation & 1 & -0.047 & $-0.116^{* *}$ \\
\hline & Sig. (2-tailed) & & 0.119 & 0.000 \\
\hline & $\mathrm{N}$ & 1078 & 1078 & 1078 \\
\hline \multirow{3}{*}{ Public reaction } & Pearson Correlation & -0.047 & 1 & $-0.69 *$ \\
\hline & Sig. (2-tailed) & 0.119 & & 0.24 \\
\hline & $\mathrm{N}$ & 1708 & 1078 & 1078 \\
\hline \multirow[t]{3}{*}{$\mathrm{N}^{\mathrm{o}}$ mentions } & Pearson Correlation & $-0.116^{* *}$ & $-0.69 *$ & 1 \\
\hline & Sig. (2-tailed) & 0.000 & 0.024 & \\
\hline & $\mathrm{N}$ & 1078 & 1078 & 1078 \\
\hline
\end{tabular}

** Correlation is significant at the 0.01 level (2-talide); ${ }^{*}$ Correlation is significant at the 0.05 level (2-tailed);

${ }^{a}$ Organization $=$ Cruz Roja Cádiz, Canal $=$ Twitter; Source. Own elaboration.

Table 9. Correlation for hashtags and mentions for CRC on Facebook.

\begin{tabular}{ccccc}
\hline \multicolumn{4}{c}{ Correlations $^{\text {a }}$} \\
\hline \multirow{3}{*}{$\mathrm{N}^{\mathrm{o}}$ hashtags } & $\mathrm{N}^{\mathrm{o}}$ hashtags & Public reaction & $\mathrm{N}^{\circ}$ mentions \\
& Pearson Correlation & 1 & -0.003 & 0.054 \\
& Sig. (2-tailed) & $\mathrm{N}$ & 0.936 & 0.175 \\
Public reaction & 622 & 622 & 622 \\
& Pearson Correlation & -0.003 & 1 & -0.021 \\
& Sig. (2-tailed) & 0.936 & & 0.609 \\
$\mathrm{~N}^{\mathrm{o}}$ mentions & $\mathrm{N}$ & 622 & 622 & 622 \\
& Pearson Correlation & 0.054 & -0.21 & 1 \\
& Sig. (2-tailed) & 0.175 & 0.609 & 622 \\
& $\mathrm{~N}$ & 622 & 622 & \\
& & & & \\
& &
\end{tabular}

** Correlation is significant at the 0.01 level (2-talide); * Correlation is significant at the 0.05 level (2-tailed);

a Organization = Cruz Roja Cádiz, Canal $=$ Facebook; Source. Own elaboration.

According to the results of Tables 9 and 11, Hypothesis 4 is not accepted for Facebook for either of the organizations analyzed. In relation to Twitter, only Hypothesis 4 for CAJ is confirmed (see Table 10). In this case, the higher number of mentions and hashtags, the lower the average public reaction. 
Table 10. Pearson correlation for hashtags and mentions in CAJ Twitter.

\begin{tabular}{ccccc}
\hline & \multicolumn{4}{c}{ Correlations $^{\text {a }}$} \\
\hline \multirow{3}{*}{$\mathrm{N}^{\mathrm{o}}$ hashtags } & $\mathrm{N}^{\circ}$ hashtags & Public reaction & $\mathrm{N}^{\mathrm{o}}$ mentions \\
& Pearson Correlation & 1 & $-0.078^{*}$ & $-0.115^{*}$ \\
& Sig. (2-tailed) & & 0.32 & 0.002 \\
Public reaction & $\mathrm{N}$ & 760 & 760 & 760 \\
& Pearson Correlation & $-0.78^{*}$ & 1 & -0.059 \\
& Sig. (2-tailed) & 0.032 & & 0.104 \\
$\mathrm{~N}^{\circ}$ mentions & $\mathrm{N}$ & 760 & 760 & 760 \\
& Pearson Correlation & $-0.115^{* *}$ & -0.059 & 1 \\
& Sig. (2-tailed) & 0.002 & 0.104 & 760 \\
\hline
\end{tabular}

** Correlation is significant at the 0.01 level (2-talide); ${ }^{*}$ Correlation is significant at the 0.05 level (2-tailed);

a Organization = Cáritas Asidonia Jerez, Canal = Twitter; Source. Own elaboration.

Table 11. Correlation for hashtags and mentions for CAJ on Facebook.

\begin{tabular}{ccccc}
\hline \multicolumn{4}{c}{ Correlations $^{\text {a }}$} \\
\hline \multirow{3}{*}{$\mathrm{N}^{\text {o }}$ hashtags } & $\mathrm{N}^{\mathrm{o}}$ hashtags & Public reaction & $\mathrm{N}^{\mathrm{o}}$ mentions \\
& Pearson Correlation & 1 & -0.039 & $0.70^{*}$ \\
& Sig. (2-tailed) & & 0.182 & 0.002 \\
Public reaction & $\mathrm{N}$ & 1148 & 1148 & 760 \\
& Pearson Correlation & -0.039 & 1 & -0.059 \\
& Sig. (2-tailed) & 0.182 & & 0.104 \\
& $\mathrm{~N}$ & 1148 & 1148 & 760 \\
$\mathrm{~N}^{\mathrm{o}}$ mentions & Pearson Correlation & -0.070 & 0.040 & 1 \\
& Sig. (2-tailed) & 0.018 & 0.176 & 760 \\
& $\mathrm{~N}$ & 1148 & 1148 & 0.05
\end{tabular}

** Correlation is significant at the 0.01 level (2-talide); * Correlation is significant at the 0.05 level (2-tailed);

a Organization = Cáritas Asidonia Jerez, Canal = Facebook; Source. Own elaboration.

Hypothesis 5. The reaction of the public depends on the link, both on Twitter and Facebook.

Likewise, and according to the results of K-W test, Hypothesis 5 is fulfilled for Facebook $(p=0.001)$ and Twitter $(p=0.0009)$ only for CRC. In this sense, the messages with links are more effective on Twitter, while on Facebook the messages are more effective without links. Regarding CAJ, Hypothesis 5 is confirmed in the case of Facebook $(p=0.000)$, where messages have more impact without links. In this sense, it is necessary to mention that the variables links, hashtags, and mentions by themselves do not explain the different reactions of the public on Twitter or Facebook. For this reason these parameters could be analyzed jointly with others, such as the theme.

\section{Conclusions}

In accordance with everything commented on so far, it can be confidently stated that SDN are very attractive communication and marketing tools for NGDOs. According to the results of the research, it can be stated that the organization's communication profile for the messages does not match the public communication profile; that is, posts on Facebook and Twitter should take into consideration the aspects that cause a greater response from the audience. For this reason, some of the findings deserve further discussion here. For example, the results indicate that in the case of both Facebook and Twitter, the organizations analyzed use them primarily as an information service, and not very often to encourage conversation. These finding are consistent with the results of other studies (Guo and Saxton 2014; Oliński and Szamrowski 2019; Saxton and Waters 2014). Another aspect to be noted is that behavioral messages have been shown to generate more responses from the public on Twitter than on Facebook. This is significant because it is not usual to write these kind of messages on Twitter, since they require complete information on how to donate or attend an event. This conclusion was also reached by Oliński and Szamrowski (2019). Furthermore, on Facebook conversational messages attract more likes and comments than informational ones, as confirmed Saxton and Waters (2014). However, behavioral messages are not usually published to make a call to volunteering, which is a 
fundamental resource for NGOs (Bales 1996; Briones et al. 2011; Zollo et al. 2019). Regarding hashtags, mentions, and external links, it is important to note that they are not a widely used resources by the NGDOs we analyzed and do not encourage audience reaction. However, other studies have demonstrated that hashtag usage was a strong indicator of retweetability (Tsur and Rappoport 2012). This could be because hashtags allow social media users to retrieve relevant information about a topic (Bonilla and Rosa 2015). A tweet being sent addresses a specific topic, and this is very useful so that users can receive information about a particular issue (Gálvez-Rodríguez et al. 2016). In this sense we must highlight that poverty and social exclusion are the topics most published by the organizations studied here, but emergencies is the topic that has caused the greatest reaction from the public. Another study on the international NPO, American Red Cross, also came to the same conclusion, and argued that Twitter is considered very useful for engaging and developing relationships with the public for coordinating emergency situations (Briones et al. 2011). There are very few tweets with the nature of a call to work as a volunteer, even though the vast majority of organizations in the annual activity report showed that they use the services of volunteers. That being said, it would be necessary to take into account other variables, such as the format and the theme together. This would allow researchers to obtain more information. Text and photo are the most commonly used format by the organizations analyzed but video format caused the largest reaction from the public on Facebook. In this sense, according to Guo and Saxton (2018), with the exception of tweets with photos, the visual content measures are largely insignificant.

Lastly, the importance of influencers should be pointed out because the information they transmit generates great impact, and their messages are shared or "liked" by a large number of users. These results were reiterated in the findings of the study carried out by Olinski and Szamrowski (2019), where they also said that influencers are the most important way of building positive relationships between an organization and their audience, mainly by commenting and disseminating the published content amongst other users. This may result in more people being able to know the work of the organizations and talk about it, thus fostering the increase of vocal advocates for the NGDOs.

Taking into account these key results, the main contribution of the present research is to cause the NGDOs to reflect on the type of publications they issue on social networks, in order to initiate actions aimed at achieving a greater reaction from the public. An example of this would be to post behavioral messages on Twitter that invite the audience to collaborate. This means that the posts have to contain all the necessary information so that monetary donation is easy and affordable, since these are the posts that have provoked the greatest reaction from the audience.

Another aspect to take into account is the extension of the research to other organizations. Although the proposed approach has been applied in two cases from the province of Cadiz, it could also be used in the analysis of other NGDOs, thus expanding the field of action to other areas, such as regional, national, or international, with the advantage of it being quantifiable; that is to say, with metrics that can measure the intended objectives.

Our study sheds light on some key elements that cause a greater reaction from the public on Twitter and Facebook, which carry important implications for the nonprofit sector. We consider that the descriptive proposal, which helps us to recognize social marketing actions in social networks, can open new lines of research in the field of NGDOs. In this setting, specific methodologies are being applied that are more in line with the nature of the information to be investigated, which occurs in real time and which is constantly changing, providing useful tools and techniques to explain how organizations relate to each other, and what is being communicated in publications online. This information will serve as a basis for future social marketing campaigns and the realization of communicative actions for the NGDOs.

Author Contributions: A.G.-C.: Introduction, theory frame, methodology, results, discussion and conclusions. J.J.M.-F.: Introduction, theory frame, methodology, results, discussion and conclusions.

Funding: This research received no external funding.

Conflicts of Interest: The authors declare no conflict of interest. 


\section{Appendix A}

Table A1. Summary of results of the hypotheses on Twitter and Facebook.

\begin{tabular}{|c|c|c|c|c|}
\hline Hypothesis (Twitter) & NGOD & Link & $p$ Value & Aceptac. \\
\hline \multirow{2}{*}{$\begin{array}{l}\text { H1. The purpose of the message influences the public's } \\
\text { reaction, both on Twitter and on Facebook. }\end{array}$} & CAJ & Greater reaction of the public in informative messages & $p=0.000$ & Yes \\
\hline & CRC & Greater public reaction to behavioral messages & $p=0.001$ & Yes \\
\hline \multirow{2}{*}{$\begin{array}{l}\text { H2. The reaction of the public is different depending on the } \\
\text { theme of the message, both on Twitter and Facebook. }\end{array}$} & CAJ & Greater reaction of the public in religious messages & $p=0.003$ & Yes \\
\hline & CRC & Greater reaction of the public in emergency messages & $P=0.000$ & Yes \\
\hline \multirow{2}{*}{$\begin{array}{l}\text { H3. The reaction of the public is different depending on the } \\
\text { format used in the messages, both on Twitter and Facebook. }\end{array}$} & CAJ & Greater reaction of the public in messages with text only & $p=0.494$ & No \\
\hline & CRC & Greater reaction of the public in messages with text and photo & $p=0.000$ & Yes \\
\hline \multirow{4}{*}{$\begin{array}{l}\text { H4. The number of mentions and hashtags influences the } \\
\text { reaction of the public, both on Twitter and Facebook. }\end{array}$} & \multirow{2}{*}{ CAJ } & \multirow{2}{*}{ Greater reaction of the public in messages containing 0 and 1 mentions, and between 1 and 2 hashtags } & M. $p=0.104$ & M. No \\
\hline & & & H. $p=0.032$ & H. Yes \\
\hline & \multirow{2}{*}{ CRC } & \multirow{2}{*}{ Greater reaction of the public in messages that have 0 and 1 hashtag, and $0-1$ mention } & M. $p=0.024$ & M. Yes \\
\hline & & & H. $p=0.119$ & H. No \\
\hline \multirow{2}{*}{$\begin{array}{l}\text { H5: The reaction of the public depends on the link, both on } \\
\text { Twitter and Facebook. }\end{array}$} & CAJ & Greater public reaction if the message does not contain links & $p=0.248$ & No \\
\hline & CRC & Greater public reaction if the message contains links & $p=0.0009$ & Yes \\
\hline Hypothesis (Facebook) & NGOD & Link & $p$ Value & Acept. \\
\hline \multirow{2}{*}{$\begin{array}{l}\text { H1. The purpose of the message influences the public's } \\
\text { reaction, both on Twitter and on Facebook. }\end{array}$} & CAJ & Greater reaction of the audience in dialogue messages & $p=0.000$ & Yes \\
\hline & CRC & Greater reaction of the audience in dialogue messages & $p=0.003$ & Yes \\
\hline \multirow{2}{*}{$\begin{array}{l}\text { H2. The reaction of the public is different depending on the } \\
\text { theme of the message, both on Twitter and Facebook. }\end{array}$} & CAJ & Greater reaction of the public in emergency messages & $p=0.000$ & Yes \\
\hline & CRC & Greater reaction of the public in prevention messages & $p=0.000$ & Yes \\
\hline \multirow{2}{*}{$\begin{array}{l}\text { H3. The reaction of the public is different depending on the } \\
\text { format used in the messages, both on Twitter and Facebook. }\end{array}$} & CAJ & Greater public reaction in video messages & $p=0.030$ & Yes \\
\hline & CRC & Greater reaction of the public in messages with text and video & $p=0.000$ & Yes \\
\hline \multirow{4}{*}{$\begin{array}{l}\text { H4. The number of mentions and hashtags influences the } \\
\text { reaction of the public, both on Twitter and Facebook. }\end{array}$} & \multirow{2}{*}{ CAJ } & \multirow{2}{*}{ Greater public reaction in messages containing between 1 and 2 hashtags and mentions } & M. $p=0.176$ & M. No \\
\hline & & & H. $p=0.182$ & H. No \\
\hline & \multirow{2}{*}{ CRC } & \multirow{2}{*}{ Greater public reaction in messages that have between 3 and 5 hashtags and between 0 and 1 mention } & M. $p=0.609$ & M. No \\
\hline & & & H. $p=0.936$ & H. No \\
\hline \multirow{2}{*}{$\begin{array}{l}\text { H5: The reaction of the public depends on the link, both on } \\
\text { Twitter and Facebook }\end{array}$} & CAJ & Greater public reaction if the message does not contain links & $p=0.000$ & Yes \\
\hline & CRC & Greater public reaction if the message does not contain links & $p=0.001$ & Yes \\
\hline
\end{tabular}




\section{References}

Aldás, Eloísa, and Montserrat Santolino. 2015. La Investigación en Comunicación y Cooperación en los nuevos escenarios de movilización social: ONGD, objetivos de justicia social y eficacia cultural. Revista de La Asociación Española de Investigación de La Comunicación 2: 1-7.

Andreasen, Alan. 1994. Social Marketing: Its Definition and Domain. Journa] of Public Policy E Marketing 13: 108-14.

Antevenio. 2016. Estudio sobre el sector de las ONGs en España. Parte II. Available online: https://www.antevenio.com/blog/2016/04/ii-estudio-sobre-el-sector-de-las-ongs-en-espana-realizado-porguiaongs-asturianos-y-gallegos-los-mas-solidarios-con-la-labor-de-las-ongs/ (accessed on 14 June 2019).

Arroyo, Isidoro, Miguel Baños, and Teresa Rodríguez. 2009. Social advertising in the NGOs of Cordoba (Argentina). Message construction profiles. Revista Latina de Comunicación Social 64: 1011-29. [CrossRef]

Arroyo, Isidoro, Miguel Baños, and Teresa Rodríguez. 2012. Modelo de investigación de las piezas audiovisuales de las organizaciones del tercer sector en redes sociales 1. Paper presented at the III Congrés Internacional Associació Espanyola d'Investigació de La Comunicació, Tarragona, Spain, January 18-20; pp. 1-18.

Arroyo, Isidoro, Antonio J. Baladró, and Rebeca Martín. 2013. Social Network Communication: Perceptions and Uses for Spanish NGOs. Cuadernos. Info 32: 77-88. [CrossRef]

Baamonde, Xosé Manuel, Alberto Pena, and Xabier Martínez. 2015. La gestión de la comunicación digital como herramienta de transparencia y rendición de cuentas en la ONGDs. Revista de La Asociación Española de Investigación de La Comunicación 2: 27-33.

Bales, Kevin. 1996. Measuring the Propensity to Volunteer. Social Policy E Adminstration 30: 206-26.

Bardin, Laurence. 1983. Análisis de contenido. Madrid: Ediciones Akal.

Bellucci, Marco, and Giacomo Manetti. 2017. Facebook as a tool for supporting dialogic accounting? Evidence from large philanthropic foundations in the United States. Accounting, Auditing \& Accountability Journal 30: 847-905.

Berends, Lynda, and Rebecca Halliday. 2018. Capacity building and social marketing promotes healthy lifestyle behaviour in an Australian Aboriginal community. Australian Journal of Rural Health 26: 279-83. [CrossRef] [PubMed]

Bernhardt, Jay M., Darren Mays, and Amanda K. Hall. 2012. Social marketing at the right place and right time with new media. Journal of Social Marketing 2: 130-37. [CrossRef]

Bonilla, Yarimar, and Jonathan Rosa. 2015. \#Ferguson: Digital protest, hashtag ethnography, and the racial politics of social media in the United States. American Ethnologist 42: 4-17. [CrossRef]

Bordarie, Jimmy. 2019. Social representations and social marketing: Effectiveness of awareness campaigns on the representation of public policies. International Journal of Nonprofit and Voluntary Sector Marketing 24: 1-11. [CrossRef]

Briones, Rowena L., Beth Kuch, Brooke F. Liu, and Yan Jin. 2011. Keeping up with the digital age: How the American Red Cross uses social media to build relationships. Public Relations Review 37: 37-43. [CrossRef]

Burton, Suzan, and Alena Soboleva. 2011. Interactive or reactive? Marketing with Twitter. Journal of Consumer Marketing 28: 491-99. [CrossRef]

Carrigan, Marylyn, and Sally Dibb. 2013. Social marketing transformed: Kotler, Polonsky and Hastings reflect on social marketing in a period of social change. European Journal of Marketing 47: 1376-98. [CrossRef]

Casais, Beatriz, and João F. Proença. 2012. Inhibitions and Implications Associated with Celebrity Participation in Health-Related Social Marketing: An Exploratory Research Focused on HIV Prevention in Portugal. Health Marketing Quarterly 29: 206-22. [CrossRef] [PubMed]

Castellano, Cristina Martorell, and Carolina Serra Folch. 2018. The Presence of NGOs on Instagram: A Case Study of Proactiva Open Arms. Trípodos 43: 83-97.

Castillo, Marco, Rogan Petrie, and Clarence Wardell. 2014. Fundraising through online social networks: A field experiment on peer-to-peer solicitation. Journal of Public Economics 114: 29-35. [CrossRef]

Cavalcanti, Johana, and Juan Sobejano. 2011. Social Media IOR_Las Relaciones como Moneda de Rentabilidad. Madrid: Bubok Publishing S.L.

Chung, Jae Eun. 2017. Retweeting in health promotion: Analysis of tweets about Breast Cancer Awareness Month. Computers in Human Behavior 74: 112-19. [CrossRef] 
Coordinadora de ONGD España. 2017. Resumen ejecutivo del informe web sobre las organizaciones de cooperación para el desarrollo. Available online: https://informe2017.coordinadoraongd.org/downloads/ informe_del_sector_2017.pdf (accessed on 14 June 2019).

Dann, Stephen. 2010. Redefining social marketing with contemporary commercial marketing definitions. Journal of Business Research 63: 147-53. [CrossRef]

Dong, Chuqing, and Hyejoon Rim. 2019. Exploring nonprofit-business partnerships on Twitter from a network perspective. Public Relations Review 45: 104-18. [CrossRef]

Dooley, Jennifer Allyson, Sandra C. Jones, and Don Iverson. 2012. Web 2.0: An assessment of social marketing principles. Journal of Social Marketing 2: 207-21. [CrossRef]

Farrow, Harmonie, and Y. Connie Yuan. 2011. Facebook to Increase Volunteerism. Journal of Computer-Mediated Communication Building 16: 115-64.

Fernandez, Miriam, Lara Piccolo, Harith Alani, Diana Maynard, Christop Meili, and Meia Wippoo. 2017. Pro-Environmental Campaigns via Social Media: Analysing Awareness and Behaviour Patterns. The Journal of Web Science 3: 1-15.

Firestone, Rebecca, Cassandra J. Rowe, Shilpa N. Modi, and Dana Sievers. 2017. The effectiveness of social marketing in global health: A systematic review. Health Policy and Planning 32: 110-24. [CrossRef] [PubMed]

Fonseca, Alexandre. 2014. Marketing digital en redes sociales: Lo imprescindible en Marketing. Available online: https: //books.google.es/books?id=ibBEBAAAQBAJ\&printsec=frontcover\&hl=es\#v=onepage\&q\&f=false (accessed on 14 June 2019).

Gálvez-Rodríguez, Maria D. M., Carmen Caba-Pérez, and Manuel López-Godoy. 2016. Drivers of Twitter as a strategic communication tool for non-profit organizations. Internet Research 26: 1052-71. [CrossRef]

García de Torres, Elvira, Lyudmyla Yezers'ka, Alejandro Rost, Mabel Calderín, Concha Edo, Miladys Rojano, Elias Said, Pedro Jeronimo, Carlos Arcila, Ana Serrano, and et al. 2011. Uso de Twitter y Facebook por los medios iberoamericanos. El Profesional de La Información 20: 611-20. [CrossRef]

Gomes, Rita Ferreira, and Beatriz Casais. 2018. Feelings generated by threat appeals in social marketing: Text and emoji analysis of user reactions to anorexia nervosa campaigns in social media. International Review on Public and Nonprofit Marketing 15: 591-607. [CrossRef]

Grunig, James, and Todd Hunt. 2000. Dirección de Relaciones Públicas. Barcelona: Gestión.

Guidry, Jeanine P. D., Richard D. Waters, and Gregory D. Saxton. 2014. Moving social marketing beyond personal change to social change: Strategically using Twitter to mobilize supporters into vocal advocates. Journal of Social Marketing 4: 240-60. [CrossRef]

Guo, Chao, and Gregory Saxton. 2014. Tweeting Social Change: How Social Media are Changing Nonprofit Advocacy. Nonprofit and Voluntary Sector Quarterly 47: 57-79. [CrossRef]

Guo, Chao, and Gregory Saxton. 2018. Speaking and Being Heard: How Nonprofit Advocacy Organizations Gain Attention on Social Media. Nonprofit and Voluntary Sector Quarterly 47: 5-26. [CrossRef]

Helmig, Bernd, and Julia Thaler. 2010. On the Effectiveness of Social Marketing.What Do We Really Know? Journal of Nonprofit $\mathcal{E}$ Public Sector Marketing 22: 264-87. [CrossRef]

Helmig, Bernd, Marc Jegers, and Irvine Lapsley. 2004. Challenges in Managing Nonprofit Organizations:A Research Overview. VOLUNTAS: International Journal of Voluntary and Nonprofit Organizations Voluntary and Nonprofit Organization 15: 101-17. [CrossRef]

Henley, Teri, and Jeanine Guidry. 2004. Online communication in nonprofit organizations. Paper presented at the Sixteenth Annual Robert B. Clarke Direct/Interactive Marketing Educators' Conference, New Orleans, LA, October 17.

Hestres, Luis. 2014. Preaching to the choir: Internet-mediated advocacy, issue public mobilization, and climate change. New Media \& Society 16: 323-39. [CrossRef]

Hootsuite. 2018. Digital Report 2018. We are Social. Available online: https://www.juancmejia.comwp-content/ uploads/2014/02/Estudio-de-estadísticas-de-Internet-y-Redes-Sociales-WeAreSocial-y-Hootsuite.pdf (accessed on 14 June 2019).

Hoover, Joe, Kate Johnson, Reihane Boghrati, Jesse Graham, and Morteza Dehghani. 2018. Moral Framing and Charitable Donation: Integrating Exploratory Social Media Analyses and Confirmatory Experimentation. Psychology 4: 1-18. [CrossRef]

IAB Spain, and Elogia. 2018. VIII Estudio anual de las rede sociales 2018. Available online: https://iabspain.es/wpcontent/uploads/estudio-redes-sociales-2018_vreducida.pdf (accessed on 14 June 2019). 
Ihm, Jennifer. 2015. Network measures to evaluate stakeholder engagement with nonprofit organizations on social networking sites. Public Relations Review 41: 17-19. [CrossRef]

Iranzo, Amador, and Alessandra Farné. 2014. Herramientas de comunicación parra el tercer sector: El uso de las redes sociales por las ONGD catalanas. COMMONS_Revista de Comunicación y Ciudadanía Digital 3: 29-50.

Jones, Sandra C., Kelly Andrews, and Kate Francis. 2017. Combining Social Norms and Social Marketing to Address Underage Drinking: Development and Process Evaluation of a Whole of Community Intervention. PLOS ONE 12: 1-14. [CrossRef]

Kannan, P. K, and Hongshuang Alice. 2017. Digital marketing: A framework, review and research agenda. International Journal of Research in Marketing 34: 22-45. [CrossRef]

Kent, Michael L., and Maureen Taylor. 2002. Toward a dialogic theory of public relations. Public Relations Review 28: 21-37. [CrossRef]

Kite, James, Bridget C. Foley, Anne C. Grunseit, and Becky Freeman. 2016. Please Like Me: Facebook and Public Health Communication. PLoS ONE 11: 1-17. [CrossRef]

Kotler, Philip. 2011. Reinventing Marketing to Manage. Journal of Marketing 75: 132-35. [CrossRef]

Krippendorff, Klaus. 1990. Metodología de análisis de contenido. Teoría y práctica. Barcelona: Paidós Comunicación.

Lai, Chih-hui, Bing She, and Chen-chao Tao. 2017. Computers in Human Behavior Connecting the dots: A longitudinal observation of relief organizations representational networks on social media. Computers in Human Behavior 74: 224-34. [CrossRef]

Lamas, Carlos. 2010. Los medios interactivos y su publicidad. La medición de audiencias. Cuadernos de Comunicación e Innovación 82: 95-101.

Landry, Réjean. 1998. L'analyse de contenu. Edited by B. Gauthier. Sillery: Presses de l’Université du Québec.

Lovejoy, Kristen, and Gregory D. Saxton. 2012. Information, Community, and Action: How Nonprofit Organizations Use Social Media. Journal of Computer-Mediated Communication 17: 337-53. [CrossRef]

Lucas, Evie. 2017. Reinventing the rattling tin: How UK charities use Facebook in fundraising. International Journal of Nonprofit and Voluntary Sector Marketing 22: 1-9. [CrossRef]

Lucerga, Maria. 2013. Nuevas herramientas para viejos interrogantes. Contradicciones de la comunicación de las organizaciones de desarrollo en la era de la solidaridad digital. COMMONS—Revista de Comunicación y Ciudadanía Digital 2: 66-90. [CrossRef]

Macia, Fernando, and Javier Gosende. 2011. Marketing Con Redes Sociales. Madrid: Anaya.

Martín, Rebeca. 2010. La comunicación web del tercer sector. Análisis estructural de los sitios web de las ONGD calificadas por la Agencia Española de Cooperación Internacional para el Desarrollo. Ph.D. thesis, University of Rey Juan Carlos, Madrid, Spain.

Mckenzie-mohr, Doug, and P. Wesley Schultz. 2014. Choosing Effective Behavior Change Tools. Social Marketing Quarterly 20: 35-46. [CrossRef]

Messner, Marcus, Maureen Linke, and Asriel Eford. 2012. Shoveling Tweets: An Analysis of the Microblogging Engagement of Traditional News Organizations. International Symposium on Online Journalism 2: 74-87. [CrossRef]

Moll, Eva. 2015. Análisis comparativo de la utilización de twitter como canal de comunicación para las principales editoriales estadounidenses y españolas. Ph.D. thesis, University Autónoma of Barcelona, Barcelona, Spain.

Moonhee, Ying, and Brandon Boatwright. 2019. Hastags Activism.pdf. Public Relations Review 45: 10-23.

Muñoz, Isabel. 2015. El alcance mediático de los gabinetes de comunicació de las ongd pro inmigrantes. Análisis de la campaña ¿Y tú de quién eres? De la fundación Sevilla Acoge en 2013. Ph.D. thesis, University of Sevilla, Sevilla, Spain.

Naik, Prasad A., and Kay Peters. 2009. A Hierarchical Marketing Communications Model of Online and Offline Media Synergies. Journal of Interactive Marketing 23: 288-99. [CrossRef]

Nelson, Erin. 2019. Come on feel the noise: The relationship between stakeholder engagement and viral messaging through an association's Twitter use. International Review on Public and Nonprofit Marketing 16: 61-79. [CrossRef]

Oliński, Marian, and Piotr Szamrowski. 2019. The Use of the Twitter in Public Benefit Organisations in Poland: How Communicative Function of Tweets Translates Into Audience Reaction? Central European Economic Journal 5: 10-24. [CrossRef]

Parkinson, Joy, Rebekah Russell-Bennett, and Josephine Previte. 2018. Challenging the planned behavior approach in social marketing: Emotion and experience matter. European Journal of Marketing 52: 837-65. [CrossRef] 
Peattie, Ken, and Sue Peattie. 2009. Social marketing: A pathway to consumption reduction? Journal of Business Research 62: 260-68. [CrossRef]

Pulido, Cristina M., Gisela Redondo, Teresa Sordé, and Ramon Flecha. 2018. Social impact in social media: A new method to evaluate the social impact of research. PLoS ONE 13: 1-21. [CrossRef] [PubMed]

PVE. 2016. Hechos y cifras del voluntariado en España 2015. Available online: http://www.fevocam.org/sites/ default/files/pve_hechos_y_cifras_del_voluntariado.pdf (accessed on 14 June 2019).

Ramil, Xose. 2012. ¿Cuál es el nuevo paradigma de la comunicación en el que nos movemos las ONG de Desarrollo? pp. 16-25. Available online: https://coordinadoraongd.org/old/1024/original/20120620_140606_ culturadigital.pdf (accessed on 14 June 2019).

Saiz, Vanesa, and Marina Mantini. 2012. Las emergencias ambientales en las redes sociales de las ONGD. Paper presented at III Congrés Internacional Associació Espanyola d'Investigació de La Comunicació, Tarragona, Spain, January 18-20.

Saunders, Stephen G, and Dani J Barrington. 2015. Redefining social marketing: Beyond behavioural change. Journal of Social Marketing 5: 160-68. [CrossRef]

Saxton, Gregory D., and Richard D. Waters. 2014. What do Stakeholders Like on Facebook? Examining Public Reactions to Nonprofit Organizations' Informational, Promotional, and Community-Building Messages. Journal of Public Relations Research 26: 280-99. [CrossRef]

Shawky, Sara, Krzyszto Kubacki, Timo Dietrich, and Scott Weaven. 2019. Using social media to create engagement: A social marketing review. Journal of Social Marketing. [CrossRef]

Silva, Filipa, Teresa Proença, and Marisa R. Ferreira. 2018. Volunteers' perspective on online volunteering-A qualitative approach. International Review on Public and Nonprofit Marketing 15: 531-52. [CrossRef]

Soboleva, Alena, Suzan Burton, Kate Daellenbach, Debra Z. Basil, Kate Daellenbach, and Debra Z. Basil. 2017. Tweets for tots: Using Twitter to promote a charity and its supporters. Journal of Consumer Marketing 34: 515-23. [CrossRef]

Soria, Ma del Mar. 2013. Métodos de sensibilización de las ONGD españolas: Una aproximación a través de la visión de las organizaciones de la COND. Revista F@ro 1: 92-103.

Soria, Ma del Mar. 2014. El mensaje informativo en Facebook y Twitter en las ONGD: Un enfoque desde suspúblicos. Revista Internacional de Comunicación 27: 1-14.

Soutter, Alistair R. B., and Simon Boag. 2019. Environmental advertising: The effect of imagery on pro-environmental attitudes and pro-environmental behaviour/Publicidad medioambiental: El efecto de las imágenes sobre las actitudes proambientales y el comportamiento proambiental. Psyecology: Revista Bilingüe de Psicología Ambiental/Bilingual Journal of Environmental Psychology 10: 88-126. [CrossRef]

Sundar, S. Shyam. 2008. The MAIN Model: A Heuristic Approach to Understanding Technology Effects on Credibility. In Digital Media, Youth, and Credibility. Edited by Miriam J. Metzger and Andrew J. Flanagin. The John D. and Catherine T. MacArthur Foundation Series on Digital Media and Learning; Cambridge: The MIT Press, pp. 73-100. [CrossRef]

Thackeray, Rosemary, Brad L. Neiger, and Heidi Keller. 2012. Integrating social media and social marketing: A four-step process. Health Promotion Practice 13: 165-68. [CrossRef] [PubMed]

Tsur, Oren, and Ari Rappoport. 2012. What's in a Hashtag?: Content Based Prediction of the Spread of Ideas in Microblogging Communities. In Paper presented at WSDM '12: Proceedings of the Fifth ACM International Conference on Web Search and Data Mining, Seattle, WA, USA, February 8-12; pp. 643-52. Available online: http://dl.acm.org/citation.cfm?doid=2124295.2124320\%5Cnpapers3://publication/doi/10.1145/2124295. 2124320 (accessed on 14 June 2019).

Veer, Ekant, Lucie Ozanne, and Michael Hall. 2015. Sharing cathartic stories online: The internet as a means of expression following a crisis event EKANT. Journal of Consumer Behaviour 15: 193-207. [CrossRef]

Wallace, Elaine, Isabel Buil, and Leslie De Chernatony. 2017. When does "liking" a charity lead to donation behaviour? European Journal of Marketing 51: 2002-29. [CrossRef]

Warrens, Matthijs J. 2011. Cohen's kappa is a weighted average. Statistical Methodology 8: 473-84. [CrossRef]

Williams, Hywel T. P., James R. McMurray, Tim Kurz, and F. Hugo Lambert. 2015. Network analysis reveals open forums and echo chambers in social media discussions of climate change. Global Environmental Change 32: 126-38. [CrossRef]

Wymer, Walter. 2017. Social marketing strategy and industry involvement. Journal of Social Marketing 7: 297-304. [CrossRef] 
Zhang, Mimi. 2010. Brands All a Twitter: The Influences of Twitter on Brands and Consumers. Ph.D. thesis, The Pennsylvania State University, State College, PA, USA.

Zollo, Lamberto, Maria Carmen, and Laudano Andrea. 2019. From governance to organizational effectiveness: The role of organizational identity and volunteers' commitment. Journal of Management and Governance 23: 111-37. [CrossRef] 